\title{
The ketamine model of positive, negative and cognitive symptoms in schizophrenia: facts and frictions
}

Citation for published version (APA):

Riedel, W. J. (2007). The ketamine model of positive, negative and cognitive symptoms in schizophrenia: facts and frictions. Journal of Psychopharmacology, 21 (3), 235-236.

https://doi.org/10.1177/0269881107078769

Document status and date:

Published: 01/01/2007

DOI:

10.1177/0269881107078769

Document Version:

Publisher's PDF, also known as Version of record

Document license:

Taverne

Please check the document version of this publication:

- A submitted manuscript is the version of the article upon submission and before peer-review. There can be important differences between the submitted version and the official published version of record.

People interested in the research are advised to contact the author for the final version of the publication, or visit the DOI to the publisher's website.

- The final author version and the galley proof are versions of the publication after peer review.

- The final published version features the final layout of the paper including the volume, issue and page numbers.

Link to publication

\footnotetext{
General rights rights.

- You may freely distribute the URL identifying the publication in the public portal. please follow below link for the End User Agreement:

www.umlib.nl/taverne-license

Take down policy

If you believe that this document breaches copyright please contact us at:

repository@maastrichtuniversity.nl

providing details and we will investigate your claim.
}

Copyright and moral rights for the publications made accessible in the public portal are retained by the authors and/or other copyright owners and it is a condition of accessing publications that users recognise and abide by the legal requirements associated with these

- Users may download and print one copy of any publication from the public portal for the purpose of private study or research.

- You may not further distribute the material or use it for any profit-making activity or commercial gain

If the publication is distributed under the terms of Article $25 \mathrm{fa}$ of the Dutch Copyright Act, indicated by the "Taverne" license above, 


\title{
The ketamine model of positive, negative and cognitive symptoms in schizophrenia: facts and frictions
}

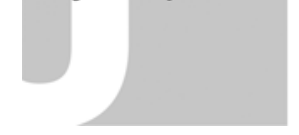

Journal of Psychopharmacology 21(3) (2007) 235-236 (C) 2007 British Association for Psychopharmacology ISSN 0269-8811 SAGE Publications Ltd, Los Angeles, London, New Delhi and Singapore $10.1177 / 0269881107078769$

\begin{abstract}
Wim J. Riedel Department of Neuropsychology and Psychopharmacology, Faculty of Psychology, University of
\end{abstract} Maastricht, The Netherlands.

In a recent issue of the Journal of Psychopharmacology (JoP), Dawson and Goodwin (2005) identified the British Association of Psychopharmacology (BAP) as well as pharmaceutical industries as the strongest supporters of Experimental Medicine - defined as the 'investigation undertaken in human beings to identify mechanisms of pathophysiology or disease, or to test the validity and importance of new discoveries or treatments, relating where appropriate to model systems'. On the preclinical side of the experimental, sometimes called 'translational' medicine equation, the combined resources of academia and industry have resulted in a phenomenal increase in fundamental knowledge, new experimental techniques and, indeed, whole new classes of candidate compounds. The latter is reflected in this special issue focusing on the ketamine model of psychotic symptoms, which contains reviews and original contributions in the experimental medicine research on glutamatergic pathways of psychotic symptoms and antipsychotic treatments.

The prototype uncompetitive $N$-methyl-D-aspartate (NMDA) receptor antagonist, phencyclidine (PCP), produced psychotic symptoms, thought disorder, blunted affect, and cognitive impairments that captured the gestalt of schizophrenia (Luby et al., 1959). Some individuals presenting to psychiatrists following PCP ingestion, generally in the context of multiple episodes of use of multiple substances, could not be distinguished from schizophrenic patients (Krystal et al., 2003). In contrast to amphetamine, which mimics only the positive symptoms of the disease, PCP induces symptoms that resemble the full range of schizophrenia's manifestations: negative and cognitive and, at times, positive. These effects are seen not just in abusers of PCP but also in individuals given brief, low doses of ketamine (an anesthetic with similar effects) in controlled drugchallenge trials (Javitt and Coyle, 2004). Ketamine subsequently emerged as the tool NMDA receptor antagonist for experimental psychopharmacological research. Ketamine, unlike PCP is still clinically available as an anesthetic that can be safely intravenously administered and titrated, does not have the disadvantages of PCP for experimental psychopharmacologic research, yet has a similar profile of effects in humans to that of PCP but with lower NMDA receptor affinity and shorter plasma half-life (Krystal et al., 2003).
In brief, the ketamine model of schizophrenia predicts that:

- ketamine transiently produces mild positive and negative psychotic symptoms;

- ketamine also induces impairments of attention, working memory, declarative memory, abstract reasoning, mental flexibility, insight, planning, and judgement;

- ketamine mimics physiologic perturbations in psychosis indexed by electrophysiological markers of sensory gating, preattentive and attentive information processing and functional neuroimaging patterns of impaired cognitive functions;

- effects of antipsychotics when administered in the context of the ketamine model both in animals and in humans manifest their effects on symptoms in a similar pattern relative to clinical manifestations;

- the ketamine model is consistent with the hypothesis of glutamatergic dysfunction in schizophrenia which entails in brief that a shortage of glutamate would increase neural activity, just as if too much dopamine were present, explaining predominantly positive symptoms, while it is noted that ketamine administration may be associated with excess glutamate in prefrontal areas and produce negative and cognitive symptoms as if too little dopamine were present.

In this issue most articles can be put in the context of seeking to confirm, add to, refine, and/or extend these observations and hypotheses.

Corlett et al. (see pp. 238) discuss delusion formation in terms of basic associative learning processes guided by the concept of prediction error, which is modulated by dopaminergic and glutamatergic pathways. They review similarities between acute psychosis and the psychotic state induced by ketamine. An outline is provided of a theoretical and experimental operational framework for investigating early stages of psychotic symptoms.

Rabiner (see pp. 253) focusing on dopamine ligand imaging reviews attempts to explain ketamine-induced symptoms by mapping effects on dopamine pathways (mainly D2-receptor). This is a 
concise review focusing on radioligand binding approaches using mainly positron emission tomography and single photon emission tomography.

Chizh (see pp. 259) presents an excellent review of ketamine as a pharmacological tool compound to investigate NMDA mediated pain pathways while illustrating the pharmacology of ketamine and integrating psychotic symptoms as side effects in the context of pain pathways.

A specific account of theoretical as well as operational aspects of the application of models such as the ketamine model in early stages of drug development is provided by Gilles and Luthringer (this issue). They review the potential application of the ketamine model in the context of accelerating proof of concept and compare the pros and cons of several similar pharmacological and physiological models.

Large (see pp. 283) critically reviews recent progress in studies of existing as well as new classes of drugs that specifically modulate glutamatergic transmission against a background of NMDA antagonist models of psychosis in animals and humans.

Cilia et al. (see pp. 302) describe an original investigation using disturbed sensory gating operationalized as ketamine-induced pre-pulse inhibition (PPI) deficits in rats as a translational model of schizophrenia with PPI as its biomarker or surrogate marker, in which effects of antipsychotic compounds are evaluated.

Heekeren et al. (see pp. 312) study PPI of the startle reflex and its attentional modulation in the human S-ketamine and N,Ndimethyltryptamine (DMT) models of psychosis. This is the only study which used the more specific S-stereo isomer form of ketamine to model psychotic effects focusing on both methods and species differences aspects of ketamine modelling.

Boeijinga et al. (see pp. 321) report about another methodological novelty which is the use of Magnetoencephalography (MEG) in the evaluation of ketamine effects and present a new type of MEG gating readout, the M100/N100, which can be viewed in the context of P50 suppression.

Covington et al. (see pp. 338) set out to compare speech abnormalities unobtrusive to the human observer, in schizophrenic patients assessed with computerized algorhythms generating syntactic and semantic measures of spoken language. Subsequently it was investigated if the observed differences were adequately modelled by ketamine in volunteers.

Finally, Uhlhaas et al. (see pp. 347) focus on a group of selfadministering ketamine abusers on- and off-drug in comparison to controls to investigate how adequate the subchronic effects of ketamine mimic symptoms seen in schizophrenic patients.

The aim of research into models and markers of a set of observations of disease symptoms and its treatment is to fully describe and understand the symptoms in the context of a set of logically coherent rules which generate testable predictions in a limited set of parameters. Improved disease understanding will facilitate this and will allow us to compare treatments in terms of their effects on specific initial markers that may predict better outcome. Within the framework of new drug development, there is a great need to make decisions in early stages of drug development whether or not a new compound has promise. This applies both at the preclinical and early clinical phases of development (i.e. Phase 1 in healthy volunteers and early phase 2 small patient studies) where the jump from knowledge about molecular mechanisms to clinical outcome is very long. It is generally accepted that animal modelling is the first intermediate step in this process of verifying the mechanism and gaining insight in pharmacodynamic effects. In the context of the glutamatergic hypothesis of schizophrenia this pertains to the ketamine model in experimental animals; and also the PCP-model and the MK-801 model. The second step could be a similar one but applied in phase 1 studies in healthy volunteers or as small Phase 2 studies in patients and this pertains exclusively to ketamine model studies. Outside the drug development arena, ketamine studies are aimed at understanding aspects of the pathophysiology of psychotic symptoms in terms of their glutamatergic basis. The work grouped together in this special issue can be viewed against this general background.

The state of affairs and results described in this issue show that we are not there yet to have a fully validated, reliable and predictive model of psychotic symptoms with easy to measure markers, which provide equally useful information in the context of the model as well as in the context of single and repeated assessment of disease symptoms and their progression over time and which distinguishes quantitatively between effects of standard and new treatments. It was special indeed to edit this special issue on a topic which has caught the imagination of psychopharmacologists from several different domains, ranging from the clinical to the molecular imaging level. The topic has intrigued cognitive neuroscientists who are specialized in the various stages and levels of information processing from the very early and low level pre-attentive gating processes, to prediction error, memory consolidation and executive cognitive control, but it has also engaged preclinical behavioural pharmacologists, who have focused on the objective and pragmatic features of investigating standard as well as new drugs in the ketamine model investigating dose-response relationships, as well as new challenges of interpretation for receptor function.

Finally, we wish to thank the contributors to this Special Issue, including those who submitted good and interesting manuscripts which unfortunately had to be rejected for various reasons. Thanks too, are due to the referees and authors for enabling us to publish this Special Issue while maintaining the highest quality standards.

\section{References}

Dawson G R, Goodwin G (2005) Experimental medicine in psychiatry. J Psychopharmacol 19: 565-566

Javitt D C, Coyle J T (2004) Decoding schizophrenia. Sci Am 290: 48-55

Krystal J H, D'Souza D C, Mathalon D, Perry E, Belger A, Hoffman R (2003) NMDA receptor antagonist effects, cortical glutamatergic function, and schizophrenia: toward a paradigm shift in medication development. Psychopharmacology 169: 215-233

Luby E D, Cohen B D, Rosenbaum G, Gottlieb J S, Kelley R (1959) Study of a new schizophrenomimetic drug; sernyl. AMA Arch Neurol Psychiatry 81: 363-369 